\title{
$\angle S$ Research Square \\ Peripheral blood lymphocytes and monocytes heterogeneity in SLE patients treated by Belimumab
}

\author{
Jinghan Yang \\ Weifang Medical University - Kuiwen Campus \\ Shushan Yan \\ Affiliated Hospital of Weifang Medical University \\ Haibo Li \\ Weifang People's Hospital \\ Chunjuan Yang \\ Weifang Medical University \\ Lili Zhang \\ Weifang People's Hospital \\ Jiamei Sun \\ Weifang People's Hospital \\ Jiaojiao Zhang \\ Weifang People's Hospital \\ Wenfeng Gao \\ Affiliated Hospital of Weifang Medical University
}

Donghua Xu ( $\nabla$ flower322@163.com )

Weifang Medical University https://orcid.org/0000-0002-9146-7858

Research article

Keywords: Systemic lupus erythematosus, Belimumab, Autoimmunity, B-lymphocyte stimulator, Immune homeostasis

Posted Date: June 16th, 2021

DOI: https://doi.org/10.21203/rs.3.rs-622554/v1

License: @ (i) This work is licensed under a Creative Commons Attribution 4.0 International License. Read Full License 


\section{Abstract}

Objective: To estimate the effect of Belimumab on the heterogeneity of peripheral blood lymphocytes and monocytes subsets in systemic lupus erythematosus (SLE).

Methods: There were three groups of populations, namely health controls ( $H C, n=92)$, SLE patients treated $(n=26)$ and un-treated with BAFF $(n=155)$ in the present study. Cell subsets of $C D 3^{+} T$ cells, $C D 3^{+} C D 4^{+} T$ cells, $C D 3^{+} C D 8^{+} T$ cells, CD $19^{+} \mathrm{B}$ cells, CD $16^{+} \mathrm{CD} 56^{+} \mathrm{NK}$ cells, CD $14^{+} \mathrm{HLA}-\mathrm{DR}{ }^{+}$monocytes, CD $14^{+} \mathrm{CD} 206^{+}$monocytes and $\mathrm{CD} 14^{+} \mathrm{CD} 163^{+}$monocytes were estimated by flow cytometry.

Results: Compared with $\mathrm{HC}$ group, SLE patients had a higher level of $\mathrm{CD} 3^{+} \mathrm{T}$ cells and $\mathrm{CD} 3^{+} \mathrm{CD} 8^{+} \mathrm{T}$ cells, but a lower level of $\mathrm{CD}^{+} \mathrm{CD} 4^{+} \mathrm{T}$ cells, CD $16^{+} \mathrm{CD} 56^{+} \mathrm{NK}$ cells, CD $14^{+} \mathrm{CD} 206^{+}$monocytes, and $\mathrm{CD} 14^{+} \mathrm{CD} 163^{+}$monocytes. Besides, the ratio of $\mathrm{CD}^{+} \mathrm{CD}^{+} / \mathrm{CD}^{+} \mathrm{CD}^{+} \mathrm{T}$ cells was much lower in SLE patients. Belimumab could effectively decrease $\mathrm{CD} 19^{+} \mathrm{B}$ cells but increase $\mathrm{CD} 3^{+} \mathrm{T}$ cell and $\mathrm{CD} 3^{+} \mathrm{CD} 8^{+} \mathrm{T}$ cells in the peripheral blood of SLE patients. Moreover, SLE patients had decreased $\mathrm{CD} 14^{+} \mathrm{CD} 206^{+}$monocytes and $\mathrm{CD} 14^{+} \mathrm{CD} 163^{+}$monocytes in peripheral blood, while Belimumab therapy did not affect the heterogeneity of monocytes in SLE.

Conclusions: Our results revealed the heterogeneity of lymphocytes and monocytes in SLE patients. The clinical efficacy of Belimumab in SLE treatment is remarkable due to its significant effect on down-regulating $B$ cell but upregulating $\mathrm{CD}^{+} \mathrm{T}$ cell and $\mathrm{CD} 3^{+} \mathrm{CD} 8^{+} \mathrm{T}$ cells in SLE.

\section{Introduction}

Systemic lupus erythematosus (SLE) is an autoimmune disease characterized by excessive activation of lymphocytes, autoantibodies generation and immune complexes deposition, which thus causes multiple systems and organs injuries [1]. The clinical manifestations are heterogeneous among SLE patients [2], including cutaneous lupus, joint pain, lupus nephritis and neuropsychiatric manifestations, and so forth [3]. Women at childbearing age are more susceptible to SLE [3]. Genetic susceptibility and environmental factors have also been elucidated in the etiology of SLE $[3,4]$. To the best of our knowledge, both innate and adaptive immune cells participate in SLE development and progression. Previous studies have demonstrated that the excessive clearance of apoptotic debris triggered abnormal activation of T cells and B cells mediated by type I interferons (IFN) and Tolllike receptors (TLRs), subsequently lead to a further cascaded expansion of immune and inflammatory responses $[5,6]$. Abnormal activation of $B$ cells and excessive antibodies production play critical roles in SLE [7]. Activated B cells can effectively present specific antigens to $T$ cells and promote the activation of $T$ cells. Abnormalities of $C D 4^{+}, C D 8^{+}$and $C D 4^{-} C D 8^{-} T$ lymphocytes are also involved in regulating inflammation and immunity in SLE [8]. Abnormal activation of immune cells leads to the imbalance of immune homeostasis and the occurrence of autoimmune diseases ultimately $[9,10]$, suggesting the vital role of immune dysregulation in the pathogenesis of autoimmune diseases.

Excessive activation of the immune system and immune escape can result in autoimmune disorders and SLE occurrence. Imbalance of lymphocytes and mononuclear macrophages has been well documented in the pathogenesis of SLE $[6,11,12]$. Currently, Belimumab (BLyS-specific inhibitor) is a new try for SLE treatment, which is a humanized monoclonal antibody targeting B-cell activating factor (BAFF), namely B-lymphocyte stimulator (BLyS). BAFF is an essential factor for the survival, differentiation, activation of $B$ cells [13]. Overexpression of BAFF can promote autoreactive B cells growth and activation [14]. Another study has verified the significant effect of Belimumab on $B$ cells in SLE [15]. BAFF in the circulation of SLE patients is suggested to be closely associated with the disease activity $[16,17]$. Therefore, anti-BAFF therapy may be promising for the treatment of SLE patients, particularly those 
difficult to obtain clinical relief. In this study, we analyze the efficacy of Belimumab for SLE by estimating the heterogeneity and phenotypic transformation of immune cells, including $\mathrm{CD} 3^{+} \mathrm{T}$ cells, $\mathrm{CD} 3^{+} \mathrm{CD} 4^{+} \mathrm{T}$ cells, $\mathrm{CD} 3^{+} \mathrm{CD} 8^{+} \mathrm{T}$ cells, CD $19^{+} \mathrm{B}$ cells, CD $16^{+} \mathrm{CD} 56^{+} \mathrm{NK}$ cells, CD $14^{+} \mathrm{HLA}-\mathrm{DR}{ }^{+}$monocytes, CD $14^{+} \mathrm{CD} 206^{+}$monocytes and CD $14^{+} \mathrm{CD} 163^{+}$ monocytes. Findings in the present study will provide novel insight into understanding the therapeutic significance of anti-BAFF treatment among SLE patients.

\section{Materials And Methods}

\subsection{Study population}

A total of 140 SLE patients untreated with Belimumab, 26 SLE patients treated with Belimumab and 92 age- and gender-matched health controls $(\mathrm{HC})$ were included in this study. All participants were recruited from the First Affiliated Hospital of Weifang Medical University between November 2019 and April 2020. This work was approved by the Institutional Ethics Committee of the First Affiliated Hospital of Weifang Medical University. All subjects had read and signed a written informed consent prior to tests. SLE patients were diagnosed according to the 1997 classification criteria for SLE revised by American College of Rheumatology [18]. All cases had received no therapeutic intervention before study. Patients with malignant tumors or any other immune diseases are all excluded. Whether treatment with Belimumab or not during the study was regarded as a criterion for distinguishing treatment from non-treatment. Characteristics of all participants were summarized in Table 1. Clinical data collected only from SLE patients are as follows: erythrocyte sedimentation rate (ESR), serum concentrations of complement factors 3 (C3) and 4 (C4) $₫$ erythrocyte count (RBC), white blood cell count (WBC), platelet count (PLT)『micro-albminuria (mALB)』antinuclear antibody (ANA) and anti-dsDNA antibody.

\subsection{Sample collection and preparation}

Peripheral blood samples were collected from HC and SLE patients. Whole blood samples were incubated directly with fluorescence labeled antibodies. Specific antibodies of CD3-FITC, CD8-PE, CD45-PerCP, CD4-APC, CD16+CD56-PE, CD19-APC were purchased from Agilent Technologies Inc. (USA). Antibodies of CD14-FITC, HLA-DR-PE, CD206-PE, and CD163-APC (BioLegend, USA) were used for detecting mononuclear macrophages according to the concentration of reagent protocols. NoveCyte flow cytometry (Agilent, USA) was used to assay all samples. Final results of percentage and absolute count of positive markers were presented. The percentage and absolute count of $\mathrm{CD}^{+} \mathrm{T}$ cells, $\mathrm{CD} 3^{+} \mathrm{CD} 4^{+} \mathrm{T}$ cells, $\mathrm{CD} 3^{+} \mathrm{CD} 8^{+} \mathrm{T}$ cells, $\mathrm{CD} 19^{+} \mathrm{B}$ cells, $\mathrm{CD} 16^{+} \mathrm{CD} 56^{+} \mathrm{NK}$ cells, ratio of $\mathrm{CD} 3^{+} \mathrm{CD} 4^{+} / \mathrm{CD} 3^{+} \mathrm{CD} 8^{+} \mathrm{T}$ cells, as well as percentage and mean fluorescence intensity (MFI) of $\mathrm{CD} 14^{+} \mathrm{HLA}-\mathrm{DR}{ }^{+}$monocytes $₫ \mathrm{CD} 14^{+} \mathrm{CD} 206^{+}$monocytes and $\mathrm{CD} 14^{+} \mathrm{CD} 163^{+}$monocytes were all estimated.

\subsection{Statistical analysis}

All statistical analyses were finished by GraphPad Prism (GraphPad Software, USA) and expressed as means \pm standard deviation (SD). Unpaired Student's t-test or paired Student's t-test was used for analysis. It is considered statistically significant, when $P$-values of two-tail were less than 0.05 .

\section{Results}

\subsection{Clinical parameters analysis in SLE patients with/without Belimumab therapy}

Data between groups were analyzed, including non-paired comparison of untreated group $(n=140) v s$ treatment group $(n=26)$, paired comparison of pre-treatment group $(n=17)$ vs post-treatment group $(n=17)$ (Table 1). The mean age in 
HC group was significantly different from untreated patients $(P<0.05)$, but no significant difference was discovered between $\mathrm{HC}$ group and the treated group $(P=0.83)$, and even between the treated group and untreated group $(P=$ $0.07)$. In addition, we found statistical significance between the three groups in this study regarding the gender status (all $P$ values less than 0.05 ).

Data with regard to ESR, C3, C4, RBC, WBC, PLT, mALB, ANA and anti-dsDNA antibody were summarized in Table 2. No significant difference was observed between the treated group and untreated group regarding all the clinical parameters except for peripheral blood PLT. The level of PLT in the treated group was higher than those in the untreated group ( $215 \pm 75.76$ vs $247.5 \pm 54.8, P \Downarrow 0.05)$. However, statistically differences of several parameters could be found between the pre-treatment and post-treatment groups, including C3, C4, PLT and mALB (Table 2). Compared with SLE patients before treatment, the serum C3 and C4 levels in patients with SLE after Belimumab treatment (for $\mathrm{C} 3,0.61 \pm 0.26$ vs $0.77 \pm 0.21, P \otimes 0.05$; for $\mathrm{C} 4,0.13 \pm 0.09$ vs $0.18 \pm 0.09, P \otimes 0.05)$ were much higher. In addition, the mean level of mALB in the post-treatment group was significantly lower than that the pre-treatment group (1410 \pm 1611 vs $686.0 \pm 1149, P \otimes 0.05)$. After treatment with Belimumab, the level of peripheral blood PLT was also increased than before treatment $(213.7 \pm 63.45$ vs $240.3 \pm 67.05, P \otimes 0.05)$. However, no difference was found in terms of $\operatorname{ESR}(P=0.09)$, $\operatorname{WBC}(P=0.15), \operatorname{RBC}(P=0.30), \operatorname{ANA}(P=0.35)$ and anti-dsDNA antibody $(P=0.29)$ between the three groups.

\subsection{Heterogeneity of lymphocyte subsets in SLE patients with/without Belimumab therapy}

The frequencies of lymphocytes $\mathrm{CD}^{+} \mathrm{T}$ cells, $\mathrm{CD} 3^{+} \mathrm{CD} 4^{+} \mathrm{T}$ cells, $\mathrm{CD} 3^{+} \mathrm{CD} 8^{+} \mathrm{T}$ cells, $\mathrm{CD} 3^{+} \mathrm{CD} 4^{+} / \mathrm{CD} 3^{+} \mathrm{CD} 8^{+} \mathrm{T}$ cells, $\mathrm{CD} 19^{+} \mathrm{B}$ cells and $\mathrm{CD} 16^{+} \mathrm{CD} 56^{+} \mathrm{NK}$ cells were evaluated by flow cytometry. All data of percentage and absolute count were summarized in Table 3 and Table 4. Figure 1 and Figure 2 also showed the differences between groups. Compared with the $\mathrm{HC}$ group, the frequency of $\mathrm{CD}^{+} \mathrm{T}$ cells in SLE group was significantly higher, no matter in Belimumab-treated group or Belimumab-untreated group (Figure 1A, 3A and 3B). By contrast, the absolute count of $\mathrm{CD}^{+} \mathrm{T}$ cells in the untreated group was lower than that in the $\mathrm{HC}$ group (Figure 2). Furthermore, both the percentage and absolute count of $\mathrm{CD} 3^{+} \mathrm{CD} 4^{+} \mathrm{T}$ cells of SLE patients without Belimumab treatment were evidently lower than those in $\mathrm{HC}$ group, while the percentage of $\mathrm{CD}^{+} \mathrm{CD} 8^{+} \mathrm{T}$ cells among the untreated patients was obviously higher than that in the $\mathrm{HC}$ group ( $P \otimes 0.05$ ) (Figure 3A, 3B). In addition, an increased percentage of $\mathrm{CD} 3^{+} \mathrm{CD} 8^{+} \mathrm{T}$ cells was found in SLE patients with Belimumab treatment $(P \otimes 0.05)$, while no significant change regarding the percentage of $\mathrm{CD} 3^{+} \mathrm{CD} 4^{+} \mathrm{T}$ cells was observed in SLE patients received Belimumab treatment when comparing with HC group (Figure 1A, 2, 3A and $3 \mathrm{~B}$ ). Besides, the ratio of $\mathrm{CD} 3^{+} \mathrm{CD} 4^{+} / \mathrm{CD} 3^{+} \mathrm{CD} 8^{+} \mathrm{T}$ cells among SLE patients with or without Belimumab treatment was significantly decreased when comparing with the HC group (Table 3). Moreover, SLE patients undergoing the treatment with Belimumab had a distinct decline of $\mathrm{CD} 19^{+} \mathrm{B}$ cells, regarding both percentage and absolute count of $\mathrm{B}$ cells when comparing with the $\mathrm{HC}$ group (Figure 1A, 2, and Figure $3 \mathrm{C}$ ). Both the percentage and absolute count of $\mathrm{CD} 19^{+} \mathrm{B}$ cells were significantly decreased in the Belimumab treated group compared with the Belimumab untreated group (Figure 1A, 2, 3C and Table 3). In addition, SLE patients treated and untreated with Belimumab had less $\mathrm{CD} 16^{+} \mathrm{CD} 56^{+} \mathrm{NK}$ cells than healthy controls, while no significant difference was observed between SLE-treated group and SLE-untreated group (Figure 1A, 2, and Figure 3D). Taken together, lymphocytes are heterogeneous in SLE, and Belimumab therapy exerts modifying effects on the differentiation of peripheral blood lymphocytes.

\subsection{Heterogeneity of monocytes in SLE patients with/without Belimumab therapy}

Monocyte subsets were estimated in peripheral blood samples from $14 \mathrm{HC}, 16$ untreated- and 16 treated- SLE patients, including CD $14^{+} \mathrm{HLA}-\mathrm{DR}{ }^{+}$monocytes, $\mathrm{CD} 14^{+} \mathrm{CD} 206^{+}$monocytes and $\mathrm{CD} 14^{+} \mathrm{CD} 163^{+}$monocytes (Table 4). The percentages of $\mathrm{CD} 14^{+} \mathrm{CD} 206^{+}$monocytes and $\mathrm{CD} 14^{+} \mathrm{CD} 163^{+}$monocytes were significantly decreased in SLE patients 
compared with healthy controls, respectively (Table 4 and Figure 4). However, there was no significant difference for $\mathrm{CD}_{14}{ }^{+} \mathrm{HLA}-\mathrm{DR}^{+}$monocytes between the three groups (Table 4). Our data only suggest a significant downregulation of M2 monocytes. In addition, the percentage and MFI of monocyte subsets between Belimumab treated group and Belimumab untreated group were not different (Table 4 and Figure 4). Taken together, SLE patients had decreased $\mathrm{CD} 14^{+} \mathrm{CD} 206^{+}$monocytes and $\mathrm{CD} 14^{+} \mathrm{CD} 163^{+}$monocytes in peripheral blood, namely M2 monocytes. Additionally, Belimumab therapy did not affect the heterogeneity of monocytes in SLE.

\subsection{Heterogeneity of lymphocytes in SLE patients before and after the treatment of Belimumab}

A total of 17 SLE patients receiving Belimumab treatment were selected for self-paired analysis before and after treatment of Belimumab. We found that the Belimumab treatment exerted inhibitory effects on CD $19^{+}$B cell, characterized by significantly decreased percentage and absolute value of CD19+ B cells (Table 5, Figure 5). Besides, the percentage of $\mathrm{CD}^{+} \mathrm{T}$ cells was also obviously increased in peripheral blood samples from SLE patients after Belimumab treatment (Table 5). Moreover, no significant difference was found between the two groups regarding $\mathrm{CD}^{+} \mathrm{CD} 4^{+} \mathrm{T}$ cells, $\mathrm{CD} 3^{+} \mathrm{CD} 8^{+} \mathrm{T}$ cells, $\mathrm{CD} 3^{+} \mathrm{CD} 4^{+} / \mathrm{CD} 3^{+} \mathrm{CD} 8^{+} \mathrm{T}$ cells and $\mathrm{CD} 16^{+} \mathrm{CD} 56^{+} \mathrm{NK}$ cells (Table 5 , Figure 5 ). We failed to estimate the effect of Belimumab on monocytes heterogeneity in SLE due to small sample size. All these results suggested that anti-BAFF treatment leaded to decreased CD $19^{+} \mathrm{B}$ cells while increased $\mathrm{CD}^{+} \mathrm{T}$ cells in SLE patients.

\section{Discussion}

Integral immune system and normal immune cell differentiation and polarization are essential for homeostasis. Abnormal lymphocytes and monocytes populations play important roles in the pathogenesis and disease progression of SLE. As a common autoimmune disease, SLE is characterized by the imbalance of lymphocyte and monocytes subsets as well as dysregulated cell functions [19-21]. BLyS is an activating factor for B lymphocytes, namely BAFF, which is crucial for the survival, differentiation, activation of B cells. It has been well documented that Belimumab can negatively regulate the activation of B cell by binding with soluble BLyS with high affinity and inhibiting its activity, whereas the efficacy of Belimumab still needs further investigation [22-24]. In the present study, we have found that Belimumab is an effective therapy for SLE patients, which can regulate the differentiation of B cells and lymphocytes in SLE.

B cells play a critical role in SLE pathogenesis [25]. Previous studies have suggested B cell dysfunction is closely related to SLE via epigenetic programming [26]. B cell deficiency results in excessive autoantibodies production, accumulation of immune complex and the activation of complement system. Wang et al. [27] have reported that the CD11 $\mathrm{c}^{\text {hi }}$ T-bet $^{+} \mathrm{B}$ cells are significantly increased in SLE, which can differentiate into autoreactive plasma cells and participate in SLE. Hyperactivation of $C D 19^{+} C D 24^{\text {hi }} C D 38^{\text {hi }}$ transitional B Cells are reported to be driven by upregulated TLR7, which elaborates their pathologic role in SLE [28]. Thus, inhibiting the differentiation and activation of B cells and plasma cells production is essential for SLE treatment. We have estimated the frequency of lymphocytes and monocytes subtypes in the peripheral blood of SLE patients with or without Belimumab treatment. The level of peripheral blood B cells in SLE patients receiving Belimumab treatment is much lower than that in those untreated patients. Besides, SLE patients in post-treated group have shown a significant decrease of B cells than the pretreated group. Nevertheless, the significant differences in B cell level between untreated SLE patients and HC were not found in our study.

Dysregulation of autoreactive B cells and T cells plays a critical role in SLE $[5,29]$. A previous study has shown that high expression of OX40L in B cells results in augment of Tfh cells, which thus contributes to SLE [30]. Tfh cells are 
responsible for regulating B cells [31]. B cells can mobilize T cells and thus initiate a series of destructive inflammatory events in SLE. Changes in immune cell frequencies and activities are closely related to the pathogenesis of SLE [32]. Similarly, imbalance of T cell subsets has been demonstrated among SLE patients in our work, characterized by decreased $\mathrm{CD} 3^{+} \mathrm{CD} 4^{+} \mathrm{T}$ cells but increased $\mathrm{CD} 3^{+} \mathrm{CD} 8^{+} \mathrm{T}$ cells in peripheral blood samples from SLE patients. Certain treatments can induce the heterogeneity of immune cells in SLE. A number of studies have documented that Belimumab exerts significant effects on B cells but not T cells [33,34]. In our study, Belimumab significantly decreases the frequency of CD19+ $\mathrm{B}$ cells in peripheral blood of SLE patients. Besides, Belimumab can promote $\mathrm{CD}^{+} \mathrm{T}$ cells among treated SLE patients compared with Belimumab untreated patients. Moreover, no significant difference is observed regarding other $T$ cell subsets as well as the ratio of $\mathrm{CD}^{+} \mathrm{CD}^{+} / \mathrm{CD}^{+} \mathrm{CD} 8^{+} \mathrm{T}$ cells between different groups. Accordingly, the significant role of Belimumab in SLE treatment is probably attributed to its altering effect on $\mathrm{CD} 19^{+} \mathrm{B}$ and $\mathrm{CD} 3^{+} \mathrm{T}$ subtypes. Nevertheless, the underlying molecular mechanism needs to be investigated in future studies.

NK cells in SLE exhibit an impairment with cytotoxic function. Increasing studies have suggested that restoration of NK cell cytotoxic function by regulating SLAMF7 and CD38 can promote plasma cell deletion and contribute to SLE improvement [35]. Our data has implicated a declined level of NK cells in SLE patients, which is consistent with findings in a previous study [32]. However, no significant influence of Belimumab on NK cells is found in this study. Increasing evidence has demonstrated the critical role of NK cells in SLE, whereas current data are not sufficient enough to support their altering effects in SLE pathogenesis. Apart from NK cells, macrophages play pivotal roles in SLE by regulating inflammatory and immune responses. When stimulated by various inflammatory stimuli, mononuclear macrophages can polarize to pro-inflammatory M1 cells, while anti-inflammatory and immunosuppressive M2 cells are significantly inhibited [36]. To the best of our knowledge, imbalance of macrophages polarization and deficiency of phagocytosis and clearance for apoptotic cells are attributed to SLE pathogenesis [37, 38]. It has been well established that TLR2/ 1 agonist PAM3 can improve the outcome of SLE by inducing monocytes polarize to M2 phenotype in NZB/W lupus model [39], which suggests the pivotal role of M1/M2 bias in maintaining immune microenvironmental balance in SLE. However, we fail to elucidate the effect of Belimumab on the polarization of monocytes in peripheral blood in SLE patients, probably due to small sample size and insufficient available data in the present study.

Lower level of complement factors is commonly found due to its excessive consumption in SLE patients. A rise of complement factors is observed merely in self-paired SLE patients after treatment by Belimumab. Many studies have implicated platelets not only participate in primary hemostasis but contribute to leukocyte recruitment and host defense against sterile inflammation as well as exogenous pathogens. The interaction between platelets and leukocytes must be tightly regulated to avoid excessive inflammation and final tissue and organ damages in SLE [40, 41]. Overactivated $B$ cells and abundant autoantibodies lead to an excessive destruction of platelets in SLE. An interesting phenomenon in our study is that significantly increased platelets is observed among SLE patients treated by Belimumab. Accordingly, our research has shown the potential therapeutic effect of Belimumab on thrombocytopenia in SLE, suggesting the inhibitory effect of Belimumab on autoantibodies production. Nevertheless, the potential mechanism warrants to be elucidated in the future.

The heterogeneity of lymphocytes and monocytes has offered new insight to the development and progression of SLE. Current evidence for the pathogenic role of B cells in SLE has emphasized that Belimumab may be an effective therapeutic strategy for SLE. Belimumab is essential for blocking B cell receptor (BCR) by combining with BAFF. Recent evidence provides insights into the mechanisms by which BAFF interact with BCR and TCR to regulate B cell survival and mobilization, which supports the value of targeted inhibition of B cells in SLE. Some previous clinical 
trials have confirmed the efficacy and safety of Belimumab in treating SLE $[42,43]$. However, little is known about the effect of Belimumab on immune cells differentiation and functions in SLE. We have demonstrated the significant heterogeneity of immune cells in peripheral blood samples from SLE patients, including those patients receiving Belimumab treatment. The most important thing is further research is needed particularly regarding the molecular mechanism of Belimumab in regulating inflammation and autoimmunity.

Findings in our study should be interpreted with caution due to several study limitations. Firstly, the main limitation of this study is the relatively small sample size. As mentioned above, we cannot elucidate the accurate effect of Belimumab on M1/M2 balance in SLE because of limited sample size and shorter observation time. Secondly, the difference between individuals is a significant confounding factor that cannot be ignored in this study. Thirdly, the modifying effects and regulatory mechanisms of Belimumab on immune cells, $T$ cell, B cell, and monocytes in particular, warrant to be investigated in future studies.

\section{Conclusion}

In summary, the heterogeneity of lymphocytes and monocytes reveals their pivotal roles in SLE immune microenvironment. Anti-BAFF treatment is a promising strategy for SLE patients, particularly those difficult to obtain clinical relief. Belimumab not only exerts its inhibitory effect on B cells but may regulate other immunes, including $T$ cell and monocytes. Last but not the least, more comprehensive research is warranted to elucidate the regulatory mechanism of Belimumab on immune cells. In addition, more clinical experiments and follow-up studies are still needed to estimate the efficacy and safety of anti-BAFF reagent, Belimumab.

\section{Abbreviations}

HC: health control; SLE: Systemic lupus erythematosus; IFN: interferons; TLRs: Tolllike receptors; BAFF: B-cell activating factor; BLyS: B-lymphocyte stimulator; ESR: erythrocyte sedimentation rate; C3: serum concentrations of complement factors 3; C4: serum concentrations of complement factors 4; WBC: white blood cell count; RBC: erythrocyte count; PLT: platelet count; mALB: micro-albminuria; ANA: antinuclear antibody; MFI: mean fluorescence intensity; SD: standard deviation; BCR: B cell receptor

\section{Declarations}

\section{Acknowledgements}

Thanks to all the colleagues in our department for their kind cooperation in this project and the patients' participation in this study.

\section{Author contributions}

JH Yang and SS Yan collected and analyzed data, conducted the experiments and drafted this manuscript; LL Zhang and HB Li collected the samples and performed the data analysis; JM Sun and CJ Yang collected the data and performed the experiments; JJ Zhang and WF Gao analyzed data and revised the draft; SS Yan and DH Xu conceived the study and proposed some discussions in this work. All authors read and approved the final manuscript.

\section{Funding}

This work is supported by funds from Shandong Natural Science Foundation (ZR2020KC001 and ZR2019QH012), National Natural Science Foundation, China (82003042), Shandong Science and Technology Development Program 
(2016WS0657), and Weifang Science and Technology Development Program (2020TX084, 2019GX031 and 2019YX020).

\section{Availability of data and materials}

Data and materials available for this study would require further approval upon request from the corresponding author.

\section{Ethics approval and consent to participate}

This work received approval from the Institutional Ethics Committee of the First Affiliated Hospital of Weifang Medical University. All subjects had read and signed a written informed consent before enrollment.

\section{Consent for publication}

Not applicable.

\section{Competing interests}

The authors declare that they have no competing interests.

\section{References}

1. Yan B, Ye S, Chen G, Kuang M, Shen N, Chen S. Dysfunctional CD4+,CD25+ regulatory T cells in untreated active systemic lupus erythematosus secondary to interferon-alpha-producing antigen-presenting cells. Arthritis Rheum. 2008;58(3):801-12.

2. Mohamed A, Chen $\mathrm{Y}, \mathrm{Wu} \mathrm{H}$, Liao J, Cheng B, Lu Q. Therapeutic advances in the treatment of SLE. Int Immunopharmacol. 2019;72:218-23.

3. Fava A, Petri M. Systemic lupus erythematosus: Diagnosis and clinical management. J Autoimmun. 2019;96:113.

4. Flesher DL, Sun X, Behrens TW, Graham RR, Criswell LA. Recent advances in the genetics of systemic lupus erythematosus. Expert Rev Clin Immunol. 2010;6(3):461-79.

5. Liu Z, Davidson A. Taming lupus-a new understanding of pathogenesis is leading to clinical advances. Nat Med. 2012;18(6):871-82.

6. Tsokos GC, Lo MS, Costa Reis P, Sullivan KE. New insights into the immunopathogenesis of systemic lupus erythematosus. Nat Rev Rheumatol. 2016;12(12):716-30.

7. Moulton VR, Tsokos GC. T cell signaling abnormalities contribute to aberrant immune cell function and autoimmunity. J Clin Invest. 2015;125(6):2220-7.

8. Klinman DM, Shirai A, Ishigatsubo Y, Conover J, Steinberg AD. Quantitation of IgM- and IgG-secreting B cells in the peripheral blood of patients with systemic lupus erythematosus. Arthritis Rheum. 1991;34(11):1404-10.

9. Gordon C, Matthews N, Schlesinger BC, Akbar AN, Bacon PA, Emery P et al. Active systemic lupus erythematosus is associated with the recruitment of naive/resting T cells. Br J Rheumatol. 1996;35(3):226-30. 
10. Odendahl M, Jacobi A, Hansen A, Feist E, Hiepe F, Burmester GR et al. Disturbed peripheral B lymphocyte homeostasis in systemic lupus erythematosus. J Immunol. 2000;165(10):5970-9.

11. Herrada AA, Escobedo N, Iruretagoyena M, Valenzuela RA, Burgos PI, Cuitino L et al. Innate Immune Cells' Contribution to Systemic Lupus Erythematosus. Front Immunol. 2019;10:772.

12. Moulton VR, Suarez-Fueyo A, Meidan E, Li H, Mizui M, Tsokos GC. Pathogenesis of Human Systemic Lupus Erythematosus: A Cellular Perspective. Trends Mol Med. 2017;23(7):615-35.

13. Moore PA, Belvedere O, Orr A, Pieri K, LaFleur DW, Feng P et al. BLyS: member of the tumor necrosis factor family and B lymphocyte stimulator. Science. 1999;285(5425):260-3.

14. Thien M, Phan TG, Gardam S, Amesbury M, Basten A, Mackay F et al. Excess BAFF rescues self-reactive B cells from peripheral deletion and allows them to enter forbidden follicular and marginal zone niches. Immunity. 2004;20(6):785-98.

15. Jacobi AM, Huang W, Wang T, Freimuth W, Sanz I, Furie R et al. Effect of long-term belimumab treatment on B cells in systemic lupus erythematosus: extension of a phase II, double-blind, placebo-controlled, dose-ranging study. Arthritis Rheum. 2010;62(1):201-10.

16. Petri M, Stohl W, Chatham W, McCune WJ, Chevrier M, Ryel J et al. Association of plasma B lymphocyte stimulator levels and disease activity in systemic lupus erythematosus. Arthritis Rheum. 2008;58(8):2453-9.

17. McCarthy EM, Lee RZ, Ni Gabhann J, Smith S, Cunnane G, Doran MF et al. Elevated B lymphocyte stimulator levels are associated with increased damage in an Irish systemic lupus erythematosus cohort. Rheumatology (Oxford). 2013;52(7):1279-84.

18. Hochberg MC. Updating the American College of Rheumatology revised criteria for the classification of systemic lupus erythematosus. Arthritis Rheum. 1997;40(9):1725.

19. Park Y, Lim J, Kim SY, Kwon GC, Koo SH, Kim J. Changes of frequency and expression level of CD161 in CD8(+) T cells and natural killer T cells in peripheral blood of patients with systemic lupus erythematosus. Microbiol Immunol. 2020;64(7):532-9.

20. Chen M, Chen X, Wan Q. Altered frequency of Th17 and Treg cells in new-onset systemic lupus erythematosus patients. Eur J Clin Invest. 2018;48(11):e13012.

21. Peng Y, Guo F, Liao S, Liao H, Xiao H, Yang L et al. Altered frequency of peripheral B-cell subsets and their correlation with disease activity in patients with systemic lupus erythematosus: A comprehensive analysis. J Cell Mol Med. 2020;24(20):12044-53.

22. Stohl W, Schwarting A, Okada M, Scheinberg M, Doria A, Hammer AE et al. Efficacy and Safety of Subcutaneous Belimumab in Systemic Lupus Erythematosus: A Fifty-Two-Week Randomized, Double-Blind, PlaceboControlled Study. Arthritis Rheumatol. 2017;69(5):1016-27.

23. Wallace DJ, Ginzler EM, Merrill JT, Furie RA, Stohl W, Chatham WW et al. Safety and Efficacy of Belimumab Plus Standard Therapy for Up to Thirteen Years in Patients With Systemic Lupus Erythematosus. Arthritis Rheumatol. 2019;71(7):1125-34. 
24. Brunner HI, Abud-Mendoza C, Viola DO, Calvo Penades I, Levy D, Anton J et al. Safety and efficacy of intravenous belimumab in children with systemic lupus erythematosus: results from a randomised, placebo-controlled trial. Ann Rheum Dis. 2020;79(10):1340-8.

25. Liossis SN, Melissaropoulos K. Molecular abnormalities of the B cell in systemic lupus erythematosus are candidates for functional inhibition treatments. Expert Opin Pharmacother. 2014;15(6):833-40.

26. Scharer CD, Blalock EL, Mi T, Barwick BG, Jenks SA, Deguchi T et al. Epigenetic programming underpins B cell dysfunction in human SLE. Nat Immunol. 2019;20(8):1071-82.

27. Wang S, Wang J, Kumar V, Karnell JL, Naiman B, Gross PS et al. IL-21 drives expansion and plasma cell differentiation of autoreactive CD11c(hi)T-bet(+) B cells in SLE. Nat Commun. 2018;9(1):1758.

28. Wang T, Marken J, Chen J, Tran VB, Li QZ, Li M et al. High TLR7 Expression Drives the Expansion of CD19(+)CD24(hi)CD38(hi) Transitional B Cells and Autoantibody Production in SLE Patients. Front Immunol. 2019;10:1243.

29. Seth A, Craft J. Spatial and functional heterogeneity of follicular helper T cells in autoimmunity. Curr Opin Immunol. 2019;61:1-9.

30. Cortini A, Ellinghaus U, Malik TH, Cunninghame Graham DS, Botto M, Vyse TJ. B cell OX40L supports T follicular helper cell development and contributes to SLE pathogenesis. Ann Rheum Dis. 2017;76(12):2095-103.

31. Ma CS, Deenick EK. Human T follicular helper (Tfh) cells and disease. Immunol Cell Biol. 2014;92(1):64-71.

32. Zhao L, Jiang Z, Jiang Y, Ma N, Wang K, Zhang Y. Changes in immune cell frequencies after cyclophosphamide or mycophenolate mofetil treatments in patients with systemic lupus erythematosus. Clin Rheumatol. 2012;31(6):951-9.

33. Stohl W, Hiepe F, Latinis KM, Thomas M, Scheinberg MA, Clarke A et al. Belimumab reduces autoantibodies, normalizes low complement levels, and reduces select $B$ cell populations in patients with systemic lupus erythematosus. Arthritis Rheum. 2012;64(7):2328-37.

34. Ramskold D, Parodis I, Lakshmikanth T, Sippl N, Khademi M, Chen Y et al. B cell alterations during BAFF inhibition with belimumab in SLE. EBioMedicine. 2019;40:517-27.

35. Humbel M, Bellanger F, Fluder N, Horisberger A, Suffiotti M, Fenwick C et al. Restoration of NK Cell Cytotoxic Function With Elotuzumab and Daratumumab Promotes Elimination of Circulating Plasma Cells in Patients With SLE. Front Immunol. 2021;12:645478.

36. Jaiswal A, Reddy SS, Maurya M, Maurya P, Barthwal MK. MicroRNA-99a mimics inhibit M1 macrophage phenotype and adipose tissue inflammation by targeting TNFalpha. Cell Mol Immunol. 2019;16(5):495-507.

37. Ma C, Xia Y, Yang Q, Zhao Y. The contribution of macrophages to systemic lupus erythematosus. Clin Immunol. 2019;207:1-9.

38. Funes SC, Rios M, Escobar-Vera J, Kalergis AM. Implications of macrophage polarization in autoimmunity. Immunology. 2018;154(2):186-95. 
39. Horuluoglu B, Bayik D, Kayraklioglu N, Goguet E, Kaplan MJ, Klinman DM. PAM3 supports the generation of M2-like macrophages from lupus patient monocytes and improves disease outcome in murine lupus. J Autoimmun. 2019;99:24-32.

40. Rossaint J, Margraf A, Zarbock A. Role of Platelets in Leukocyte Recruitment and Resolution of Inflammation. Front Immunol. 2018;9:2712.

41. Linge P, Fortin PR, Lood C, Bengtsson AA, Boilard E. The non-haemostatic role of platelets in systemic lupus erythematosus. Nat Rev Rheumatol. 2018;14(4):195-213.

42. Navarra SV, Guzman RM, Gallacher AE, Hall S, Levy RA, Jimenez RE et al. Efficacy and safety of belimumab in patients with active systemic lupus erythematosus: a randomised, placebo-controlled, phase 3 trial. Lancet. 2011;377(9767):721-31.

43. Furie R, Petri M, Zamani O, Cervera R, Wallace DJ, Tegzova D et al. A phase III, randomized, placebo-controlled study of belimumab, a monoclonal antibody that inhibits $B$ lymphocyte stimulator, in patients with systemic lupus erythematosus. Arthritis Rheum. 2011;63(12):3918-30.

\section{Tables}

Table 1. Demographic and clinical data of Study Samples

\begin{tabular}{llll}
\hline Feature & HC & Belimumab-treated SLE & Belimumab-untreated SLE \\
\hline Sample size & 92 & 26 & 140 \\
Age (year) & $31.73 \pm 7.74$ & $32.15 \pm 11.14$ & $36.76 \pm 12.18 *$ \\
Male & 2 & 4 & 10 \\
Female & 90 & 22 & 130 \\
\hline
\end{tabular}

Data are presented as mean \pm SD. $* \square$ compared with HC group, $P<0.05 \square \square$ compared with that Belimumab treated group, $P<0.05$ (Student's t-test).

Table 2 Clinical data from SLE patients 


\begin{tabular}{|c|c|c|c|c|}
\hline & $\begin{array}{l}\text { Belimumab- } \\
\text { untreated } \\
(n=140)\end{array}$ & $\begin{array}{l}\text { Belimumab- } \\
\text { treated } \\
(\mathrm{n}=26)\end{array}$ & $\begin{array}{l}\text { Pre-treatment } \\
(\mathrm{n}=17)\end{array}$ & $\begin{array}{l}\text { Post-treatment } \\
(n=17)\end{array}$ \\
\hline $\begin{array}{l}\text { ESR } \\
(\mathrm{mm} / \mathrm{h})\end{array}$ & $24.8 \pm 22.97$ & $17.04 \pm 10.73$ & $24.13 \pm 13.98$ & $18.53 \pm 10.76$ \\
\hline $\begin{array}{l}\text { C3 } \\
(g / L)\end{array}$ & $1.38 \pm 4.82$ & $0.75 \pm 0.23$ & $0.61 \pm 0.26$ & $0.77 \pm 0.21 \Delta$ \\
\hline $\begin{array}{l}\text { C4 } \\
(g / L)\end{array}$ & $0.16 \pm 0.09$ & $0.18 \pm 0.1$ & $0.13 \pm 0.09$ & $0.18 \pm 0.09 \Delta$ \\
\hline $\begin{array}{l}\text { WBC } \\
\left(\times 10^{\wedge} 9 / \mathrm{L}\right)\end{array}$ & $8.15 \pm 23.92$ & $5.99 \pm 2.35$ & $6.71 \pm 2.11$ & $6.02 \pm 2.35$ \\
\hline $\begin{array}{l}\text { RBC } \\
\left(\times 10^{\wedge} 9 / \mathrm{L}\right)\end{array}$ & $7.0 \pm 32.48$ & $4.4 \pm 0.57$ & $4.3 \pm 0.7$ & $4.41 \pm 0.67$ \\
\hline $\begin{array}{l}\text { PLT } \\
\left(\times 10^{\wedge} 9 / \mathrm{L}\right)\end{array}$ & $215 \pm 75.76$ & $247.5 \pm 54.8 *$ & $213.7 \pm 63.45$ & $240.3 \pm 67.05 \Delta$ \\
\hline $\begin{array}{l}\mathrm{mALB} \\
(\mathrm{mg} / \mathrm{LD}\end{array}$ & $453.5 \pm 1088$ & $512.0 \pm 915.7$ & $1410 \pm 1611$ & $686.0 \pm 1149 \Delta$ \\
\hline $\begin{array}{l}\text { ANA } \\
(\mathrm{au} / \mathrm{mL})\end{array}$ & $319.5 \pm 192.4$ & $306.3 \pm 293.8$ & $329.2 \pm 167.8$ & $392.4 \pm 181.9$ \\
\hline $\begin{array}{l}\text { Anti-dsDNA } \\
\text { antibody } \\
(\mathrm{u} / \mathrm{MI})\end{array}$ & $101.3 \pm 97.92$ & $148.6 \pm 128.3$ & $144.1 \pm 123.1$ & $164.5 \pm 147.0$ \\
\hline
\end{tabular}

Data are presented as mean \pm SD. ESR, erythrocyte sedimentation rate $(0-20 \mathrm{~mm} / \mathrm{h})$; C3, serum concentrations of complement factors 3 (0.79-1.52g/L); C4 घserum concentrations of complement factors

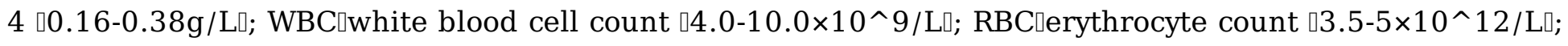

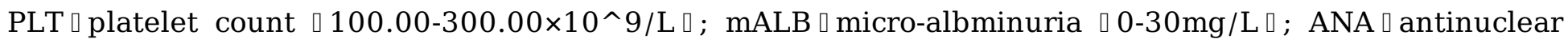
antibody $\square$ 0-32au/mL $\square$; Anti-dsDNA antibody $\square 0-25 \mathrm{u} / \mathrm{MI} \square .{ }^{*} \square$ compared with untreated group, $\mathrm{P}<0.05 \square \square$ compared with that pre-treated group, $\mathrm{P}<0.05$ (Student's t-test).

Table 3. Distribution of lymphocyte subsets in three study groups. 
HC

SLE untreated with Belimumab

SLE treated with Belimumab

\begin{tabular}{|c|c|c|c|c|c|c|}
\hline & $\begin{array}{l}\text { Percentage } \\
(\%)\end{array}$ & Absolute count & $\begin{array}{l}\text { Percentage } \\
(\%)\end{array}$ & $\begin{array}{l}\text { Absolute } \\
\text { count }\end{array}$ & $\begin{array}{l}\text { Percentage } \\
(\%)\end{array}$ & $\begin{array}{l}\text { Absolute } \\
\text { count }\end{array}$ \\
\hline $\mathrm{CD}^{+}$ & $71.94 \pm 6.72$ & $1384 \pm 418.3$ & $\begin{array}{l}79.11 \pm 9.74 \\
*\end{array}$ & $\begin{array}{l}1058 \pm 741.8 \\
*\end{array}$ & $86.2 \pm 7.3 * \boldsymbol{\Delta}$ & $1279 \pm 610.3$ \\
\hline $\mathrm{CD}^{+} \mathrm{CD}^{+}$ & $37.67 \pm 6.81$ & $721.7 \pm 233.4$ & $\begin{array}{l}35.14 \pm 8.79 \\
*\end{array}$ & $\begin{array}{l}484.4 \pm 410.9 \\
*\end{array}$ & $37.2 \pm 10.48$ & $\begin{array}{l}555.2 \pm 330.7 \\
*\end{array}$ \\
\hline $\mathrm{CD}^{+} \mathrm{CD}^{+}$ & $29.73 \pm 5.83$ & $574.5 \pm 204.2$ & $\begin{array}{l}40.84 \pm 11.48 \\
*\end{array}$ & $536 \pm 358.2$ & $\begin{array}{l}45.55 \pm 12.82 \\
*\end{array}$ & $667.3 \pm 363.8$ \\
\hline $\begin{array}{l}\mathrm{CD}^{+} \mathrm{CD}^{+} / \\
\mathrm{CD}^{+}{ }^{+} \mathrm{CD}^{+}\end{array}$ & $1.34 \pm 0.47$ & -- & $0.97 \pm 0.48 *$ & -- & $0.92 \pm 0.43 *$ & -- \\
\hline $\mathrm{CD} 9^{+}$ & $11.41 \pm 3.17$ & $218.8 \pm 87.31$ & $11.06 \pm 7.82$ & $\begin{array}{l}141.6 \pm 128.4 \\
*\end{array}$ & $\begin{array}{l}3.85 \pm 3.41 \\
* \boldsymbol{\Lambda}\end{array}$ & $\begin{array}{l}53.5 \pm 53.59 \\
* \boldsymbol{\Lambda}\end{array}$ \\
\hline $\mathrm{CD} 16^{+} \mathrm{CD} 56^{+}$ & $15.41 \pm 6.76$ & $294.6 \pm 153.9$ & $8.57 \pm 6.21 *$ & $\begin{array}{l}110.6 \pm 158.3 \\
*\end{array}$ & $8.06 \pm 7.44 *$ & $\begin{array}{l}113.8 \pm 133.9 \\
*\end{array}$ \\
\hline
\end{tabular}

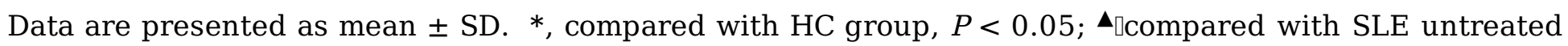
group, $P<0.05$ (Student's t-test).

Table 4. Distribution of monocyte subsets in HC, SLE untreated and treated with Belimumab.

\begin{tabular}{|c|c|c|c|c|c|c|}
\hline & \multicolumn{2}{|c|}{$\mathrm{CD}^{14}{ }^{+}$HLA-DR ${ }^{+}$monocyte } & \multicolumn{2}{|c|}{$\mathrm{CD}_{14}{ }^{+} \mathrm{CD} 06^{+}$monocyte } & \multicolumn{2}{|c|}{$\mathrm{CD}_{14}{ }^{+} \mathrm{CD} 163^{+}$monocyte } \\
\hline & $\begin{array}{l}\text { Percentage } \\
(\%)\end{array}$ & MFI & $\begin{array}{l}\text { Percentage } \\
\text { (\%) }\end{array}$ & MFI & $\begin{array}{l}\text { Percentage } \\
\text { (\%) }\end{array}$ & MFI \\
\hline$H C(n=14 \square$ & $97.80 \pm 3.03$ & $11365 \pm 2533$ & $22.06 \pm 11.29$ & $4330 \pm 2099$ & $98.34 \pm 2.52$ & $5638 \pm 1832$ \\
\hline $\begin{array}{l}\text { SLE untreated } \\
\text { with } \\
\text { Belimumab } \\
(n=16)\end{array}$ & $95.68 \pm 4.28$ & $20457 \pm 27742$ & $\begin{array}{l}8.79 \pm 14.89 \\
*\end{array}$ & $14693 \pm 23161$ & $82.95 \pm 9.31 *$ & $\begin{array}{l}3228 \pm 1909 \\
*\end{array}$ \\
\hline $\begin{array}{l}\text { SLE treated } \\
\text { with } \\
\text { Belimumab } \\
(n=16)\end{array}$ & $95.97 \pm 3.63$ & $12167 \pm 3235$ & $5.14 \pm 9.66 *$ & $13310 \pm 17834$ & $85.24 \pm 6.2 *$ & $\begin{array}{l}3127 \pm 1717 \\
*\end{array}$ \\
\hline
\end{tabular}

Data are presented as mean $\pm \mathrm{SD}$. *, compared with HC group, $P<0.05$ (Student's t-test). 
Table 5. Distribution of Lymphocyte subsets in patients with SLE before and after Belimumab treatment.

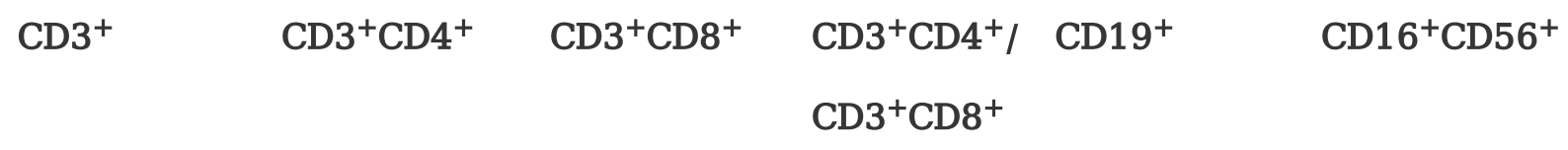

SLE pre-treated with Belimumab ( $\mathrm{n}=17)$

Percentage $80.2 \pm 7.8 \quad 34.11 \pm 10.82 \quad 43.11 \quad \pm 0.89 \pm 0.5 \quad 8.61 \pm 4.6 \quad 8.8 \pm 7.1$

(\%)

10.72

\begin{tabular}{|c|c|c|c|c|c|c|c|}
\hline \multirow[t]{2}{*}{ Absolute value } & $1100 \pm 825.4$ & $481.0 \pm 386.3$ & 578.2 & \pm & 一 & 133.4 & \pm 110.8 \\
\hline & & & 437.3 & & & 119.2 & 118.1 \\
\hline
\end{tabular}

SLE post-treated with Belimumab $(n=17)$

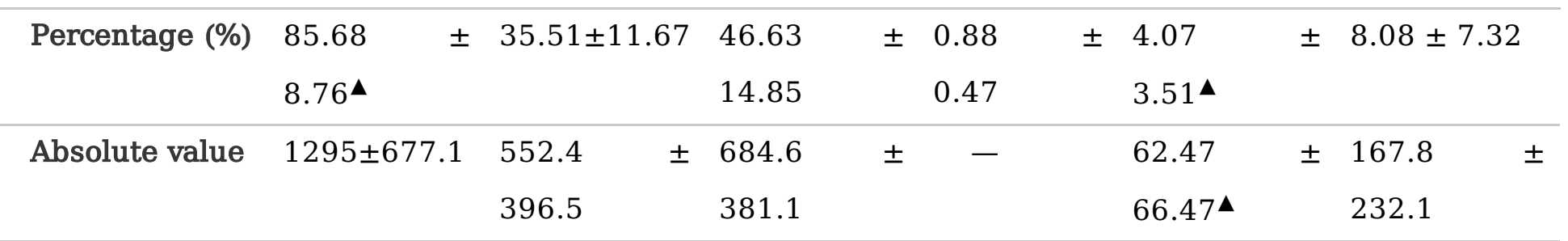

Data are presented as mean \pm SD. $\Delta_{\square}$ compared with SLE pre-treated with Belimumab group, $P<0.05$ (self-paired t-test).

\section{Figures}

A

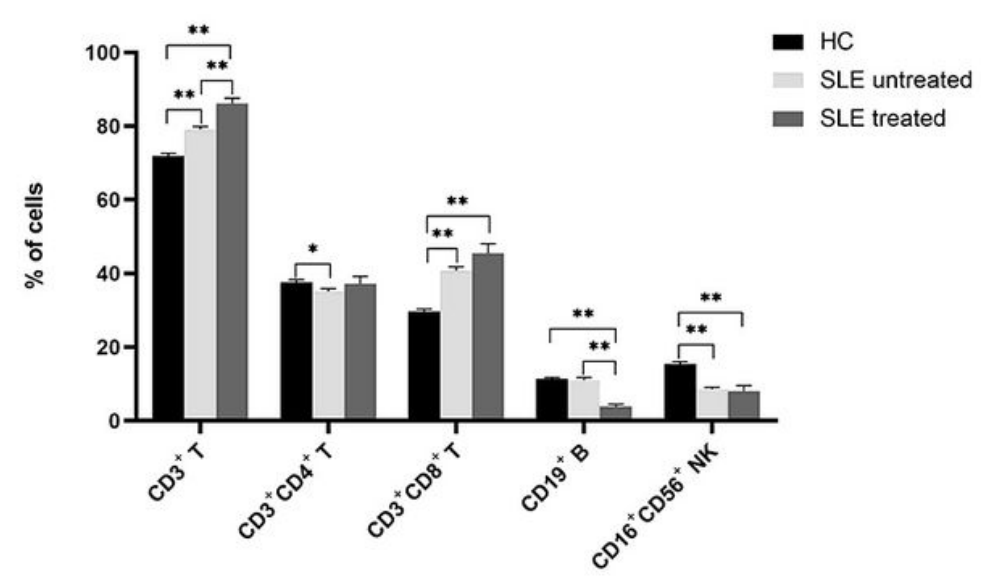

B

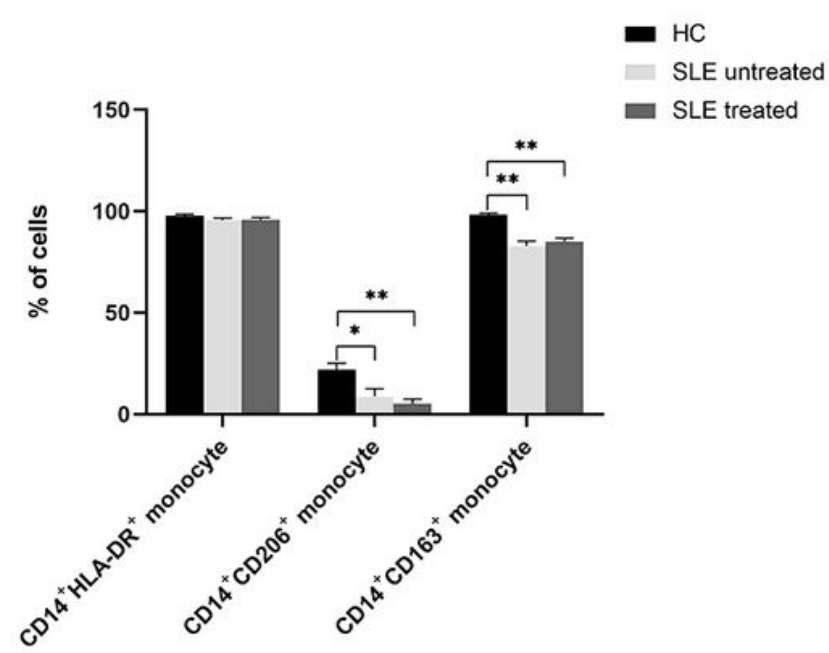

\section{Figure 1}

Frequencies of immune cells in peripheral blood samples. SLE patients have higher level of CD3+ $T$ cells and CD3+CD8+ T cells than HCs, while lower level of CD3+CD4+ T cells, CD16+CD56+ NK cells, CD14+CD206+ monocytes and CD14+CD163+ monocytes. Belimumab treatment led to decreased CD19+ B cells and CD3+ T cell. *, $P<0.05 ; * *$, $P<0.01$. 


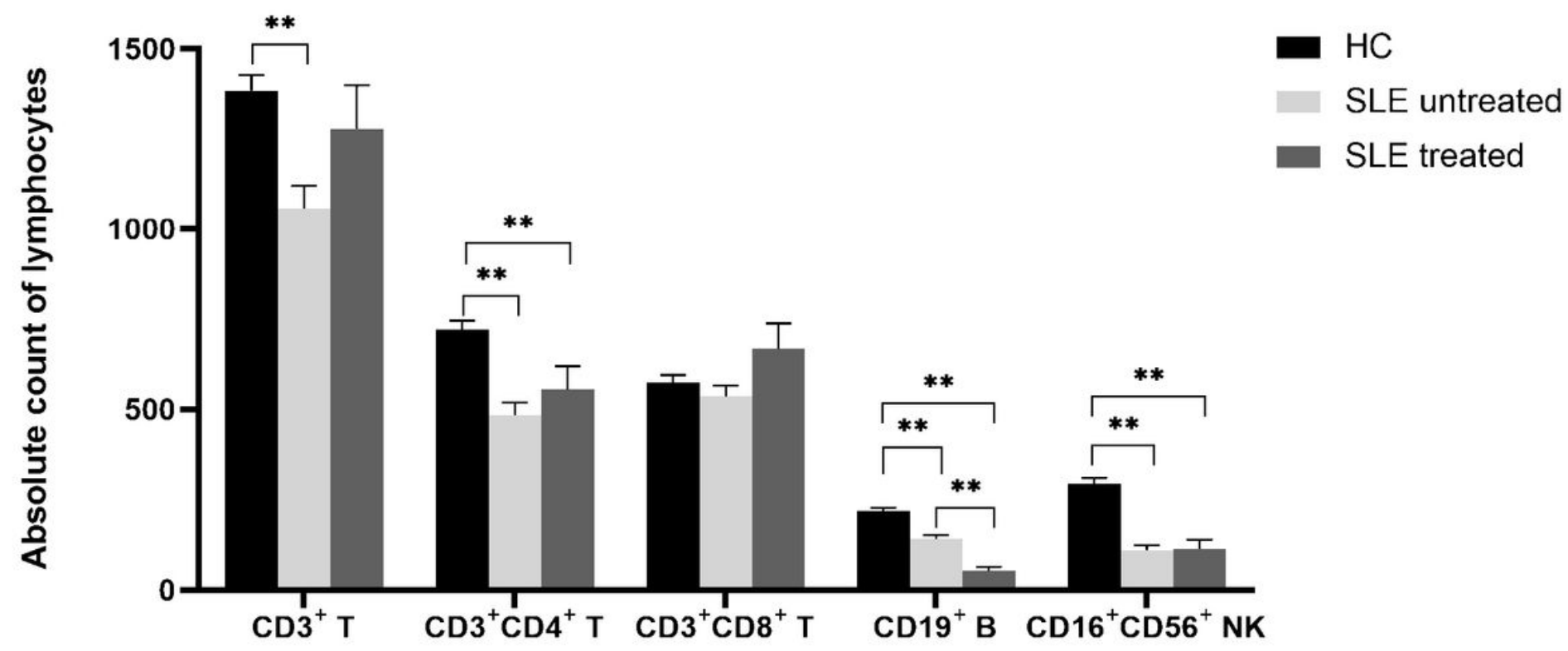

Figure 2

Absolute count of lymphocytes in peripheral blood samples. CD3+ T cells $\varangle C D 3+C D 4+T$ cells $\varangle C D 19+B$ cells and CD16+CD56+ NK cells in patients were significantly lower than HCs. A significant decrease of CD19+ B cells was found in SLE patients in response to Belimumab treatment. *, $\mathrm{P}<0.05 ;$ **, $\mathrm{P}<0.01$. 

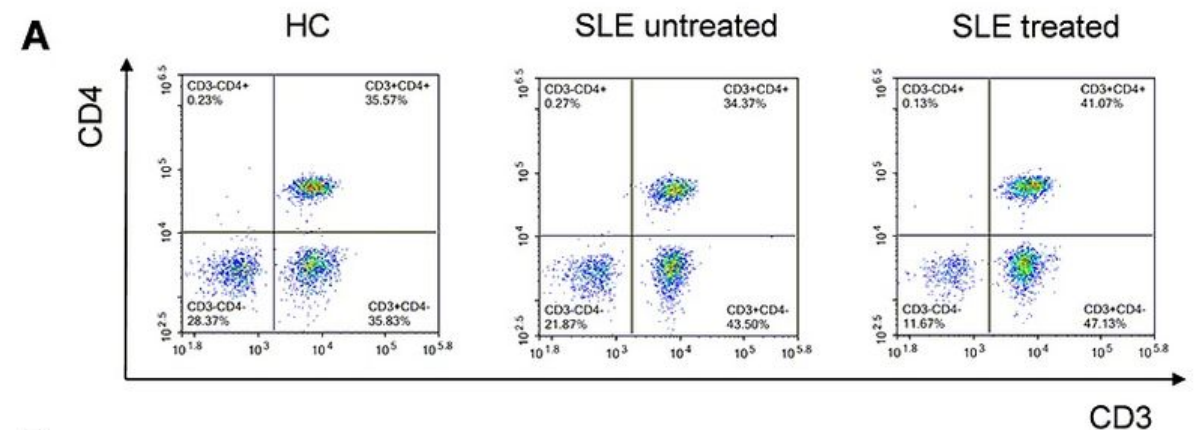

B

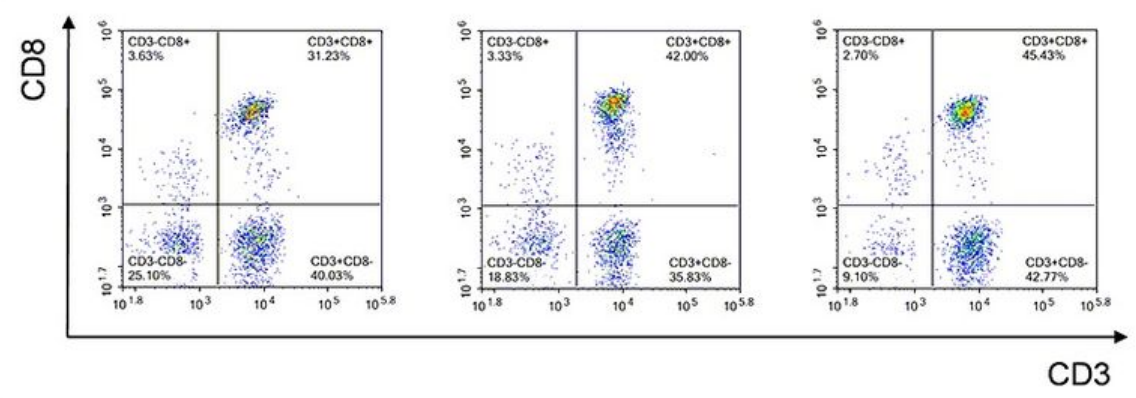

C
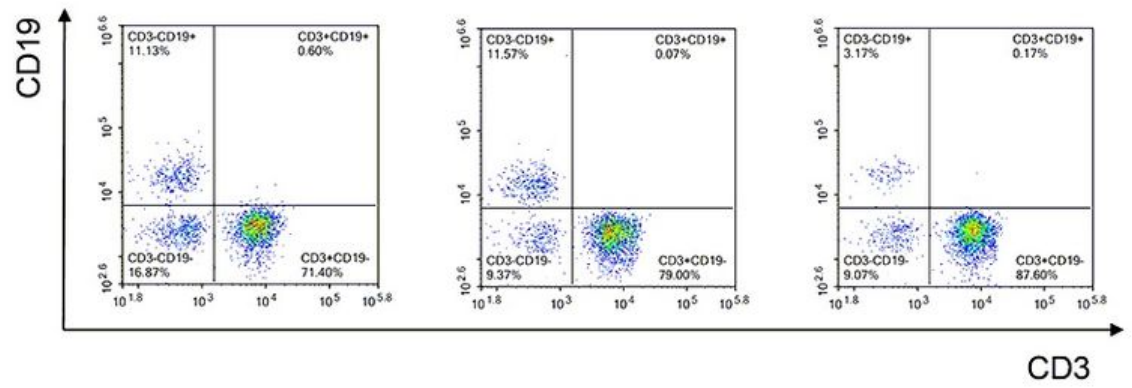

D

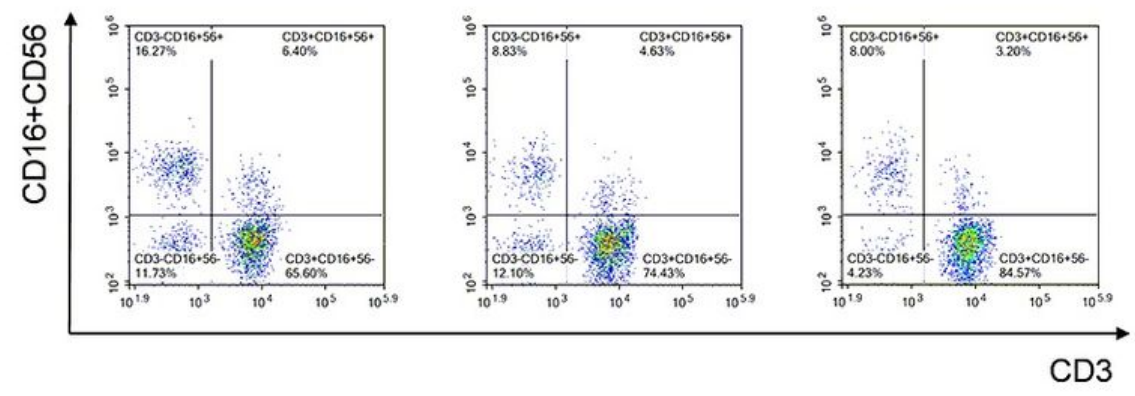

Figure 3

Representative pictures for flow cytometry: CD3+CD4+ T cell, CD3+CD8+ T cell, CD19+ B cell and CD16+CD56+ NK cell between groups. 
A

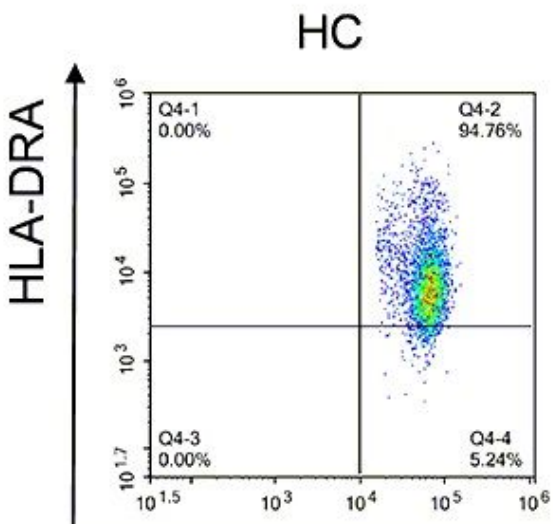

B

0
ปิ

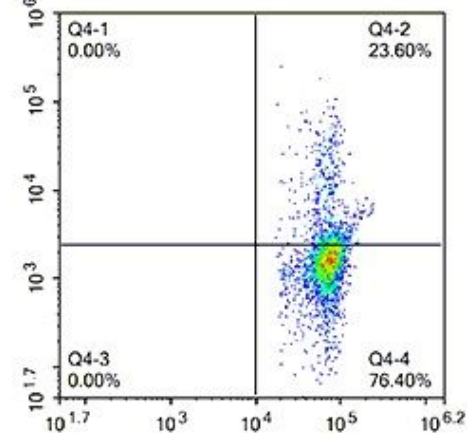

SLE untreated

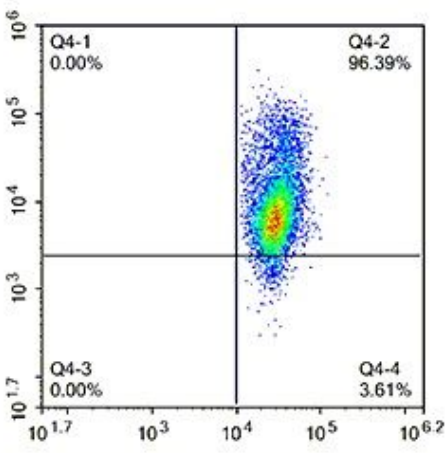

SLE treated

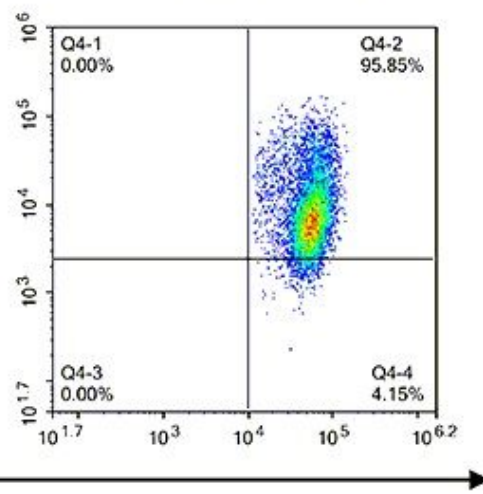

CD14
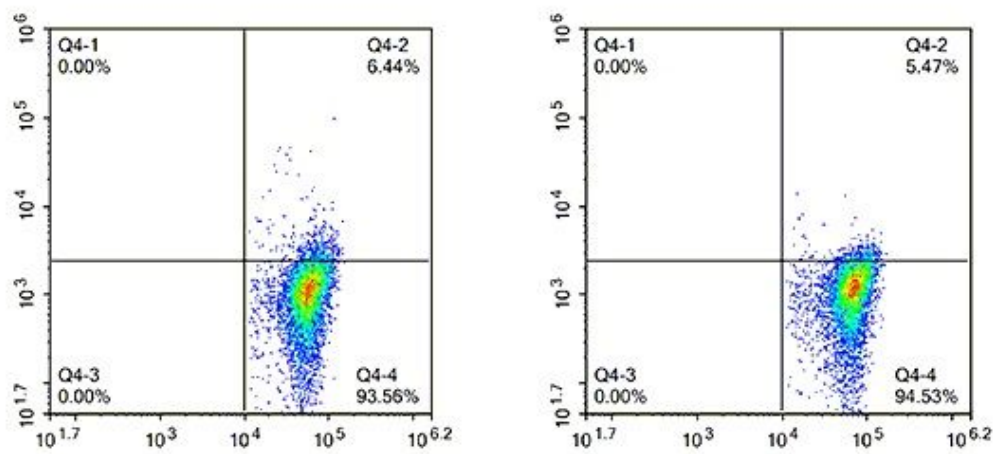

CD14

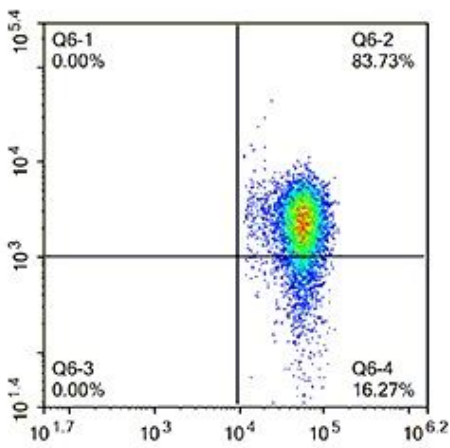

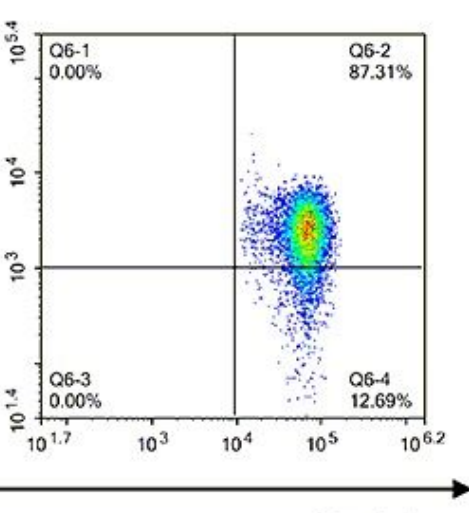

CD14

\section{Figure 4}

Representative pictures for flow cytometry: CD14+HLA-DR+ monocyte, CD14+CD206+ monocyte and CD14+CD163+ monocyte between groups. 


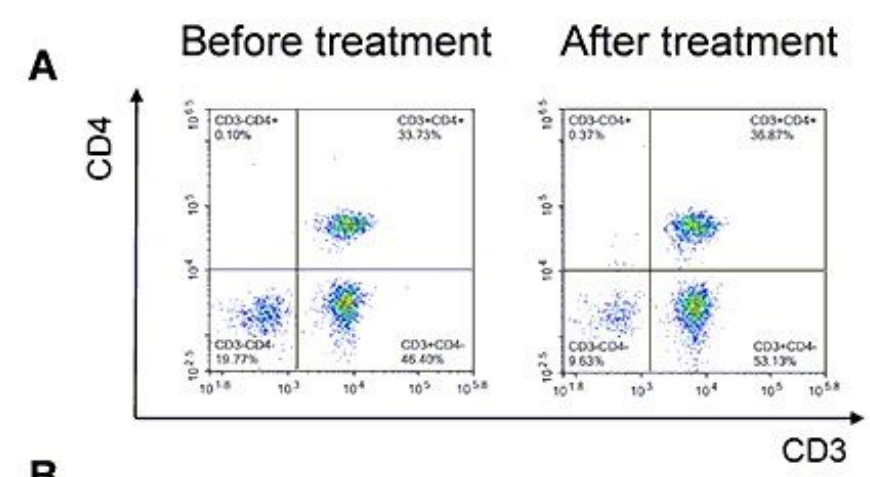

B

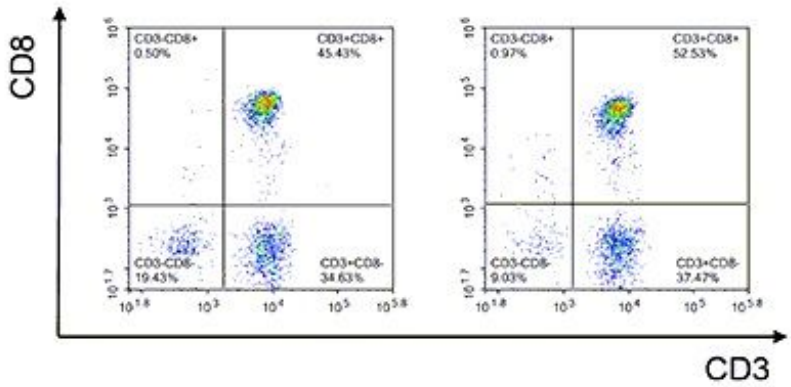

C
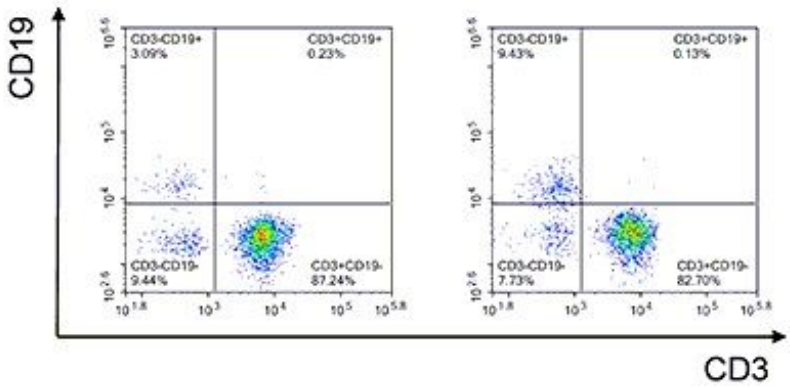

D

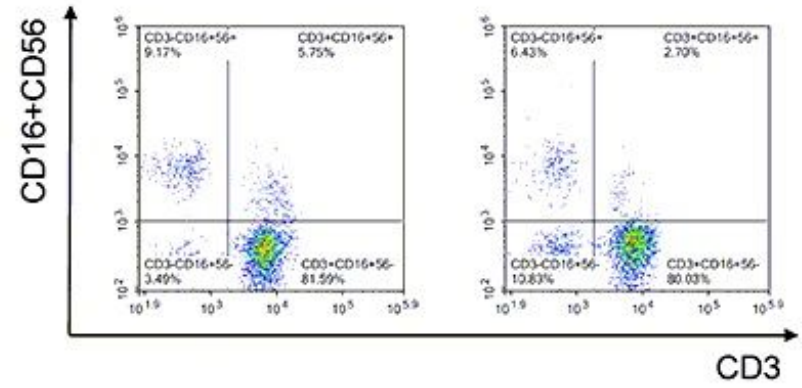

Figure 5

Representative pictures for flow cytometry: CD3+CD4+ T cell, CD3+CD8+ T cell, CD19+ B cell and CD16+CD56+ NK cell between groups. 